\title{
STATE OF DIGITAL LITERACY: PREPAREDNESS OF HIGHER EDUCATION STUDENTS FOR E- ADMINISTRATION IN HUNGARY
}

\author{
László Berényi ${ }^{1}$ and Péter László Sasvári ${ }^{2}$
}

DOI: $10.24989 /$ ocg.v331.29

\begin{abstract}
Taking the advantages of electronic administration requires a comprehensive development program. Beyond the technical background, databases and user interfaces, it is necessary to consider personal aspects including preparedness of users and administrators. Increasing the confidence in e-administration is difficult to reach without their advanced IT and ICT competencies. The main challenge can be formulated as improving digital literacy. If receptiveness for novel technological solutions fails, efforts may become redundant. Successful actions in this field are not available without the thorough analysis of present state and critical knowledge elements. The paper summarizes some results of a diagnostic analysis about the ICT utilization in order to establish further research actions about task-technology fit in the field. Research sample consists of public administration students who will play an important role in realizing e-governance. Results show that technical background, as well as general utilization of ICT tools, are no more bottlenecks of success; however, there are relevant education challenges on developing digital literacy.
\end{abstract}

\section{Introduction}

Developing e-solutions is a key driving factor both for business and public administration. There are fundamental changes both in official administration and personal communication. The virtualization of our life became general; information technology (IT) and info-communication tools (ICT) integrate everyday activities [13]. ICT tools represent the link between the knowledge and skills and the user, however, the ability to use them is also inevitable. Consequently, establishing successful solutions instead of generating more problems requires a comprehensive set of actions including an info-communications strategy, supporting the development of hardware elements and networks as well as solving education challenges. The last one covers improving the users' skills and increasing the level of acceptance. There is a need for a technological development (see [16]) that assumes the evolution of digital literacy in parallel with technical development. Digital literacy enables us to match the medium to the information presented and to the audience targeted [12]. Eshet-Alkalai [6] defined the term as "survival skill in the digital era" referring to the context and responsibility of formal education. Furthermore, the present students will enter the labor market within a few years that will generate additional tasks that are expected to be solved through digital literacy and open new aspects of the digital world to learn.

\section{Task-technology fit}

Quality evaluation models summarized by Isaias and Issa [11] may support to monitor the progress of IT and ICT-related development and to designate intervention points in order to achieve strategic

\footnotetext{
${ }^{1}$ National University of Public Administration, Institute of E-Government, berenyi.laszlo@uni-nke.hu

${ }^{2}$ National University of Public Administration, Institute of E-Government, sasvari.peter@uni-nke.hu
} 
goals. There are various frameworks and models developed in the past decades with some common characteristics:

- environmental factors are considered,

- $\quad$ attitudes and/or intention to activities are involved,

- $\quad$ there is a feedback mechanism that may confirm the usefulness of the activities.

- $\quad$ assumes that the solution is available and knows by the user.

There is another approach is presented in the task-technology fit models (see [11], [5]) with the core idea that performance and satisfaction can be evaluated in the knowledge of task characteristics (similarly to the product-based approach of quality [7]). Task-technology fit can be understood as a quality indicator of a technology meeting the current requirements. There are several approaches; even the original interpretation [10] includes more models (Figure 1), but the scope of revisions is rich (see e.g. [4], [8], [11]).

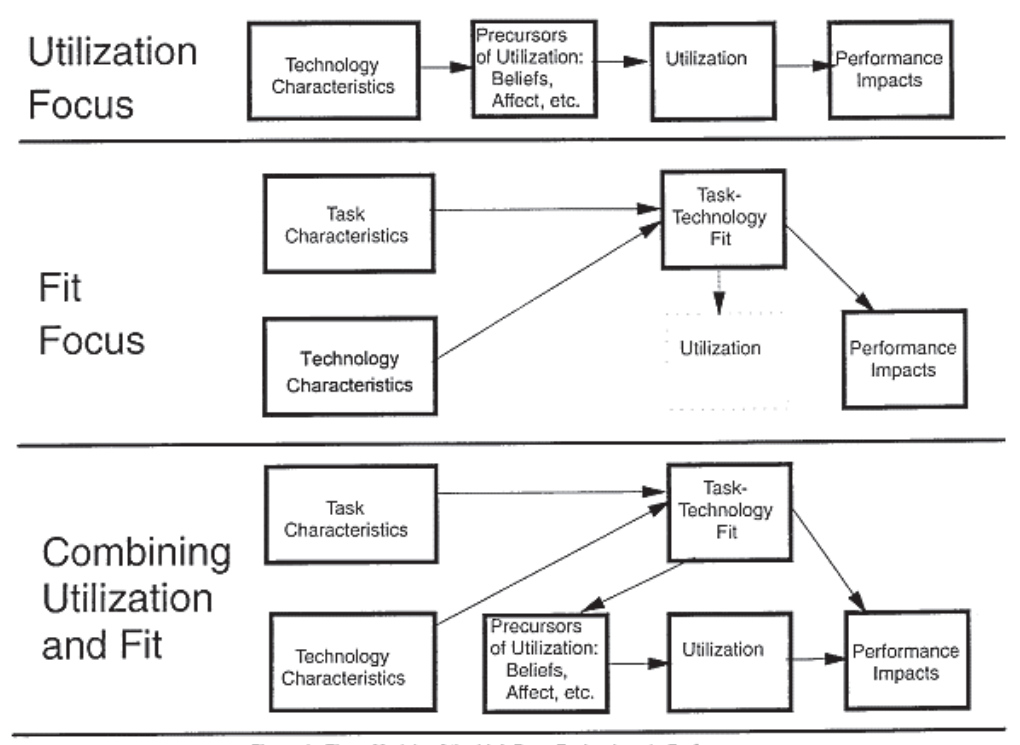

Figure 1. Three Models of the Link From Technology to Performance

Figure 1: Three models of the link from technology to performance [10]

\section{Research goals and sample}

Goodhue and Thompson [10] draw attention to the limitation that task-technology fitting (fit focus model) is difficult measure in general since utilization is a complex outcome; however, it may be worth to perform an analysis with a wider focus to prepare further research. Our paper attempts to review some aspects of the task-technology fit of ICT tools use among public administration higher education students. Obviously, each task requires an individual analysis, however, we believe that the task-technology fit models, especially the approach of the fit focus model are suitable for 
evaluating the progression. This needs the general categorization of the tasks and the review of the available technological background. Currently, a detailed analysis based on the task-technology fit model is not feasible, the purpose of the paper is to designate the basis of a further research model in the field.

The paper deals with following issues:

- technology characteristics is described based on the statistics on the availability and the utilization of ICT tools and networks by the recent reports of the Hungarian Central Statistical Office in the field;

- $\quad$ task characteristics aims to collect frequent tasks performed by ICT tools;

- $\quad$ performance is concluded based on personal satisfaction and some competencies.

This pilot investigation aims the public administration higher education students of the National University of Public Service since their competencies as both users and providers are a key success factor of the efforts on developing e-administration. A deeper analysis of the field is necessary since digital literacy of them may be considered as a key driving force of enhancing the e-government. Computer use is evident in the target group, these students can be considered as frequent ICT users. The method of the investigation used a self-filling survey managed by the EvaSys e-survey system. Statistical analysis allows checking whether the virtualization and utilization of the mobile/portable ICT tools play an increasing role in their life that may contribute to the acceleration of the related development efforts.

The target group included the students of the subject 'Public administration information technology and information systems II". There were 243 full-time and 111 part-time students learning this subject in the fall of 2017. Each student received a message through the study administration system, including a link to the questionnaire. The participation was voluntary. $12.7 \%$ of the students answered the questions. The research sample consists of the answers of 45 bachelor level students. $77.8 \%$ of them are females; $71,1 \%$ are full-time students. The representativeness of the sample is not assured, interpretation of the figures and findings are limited to the sample. However, these results allow establishing questions related to the availability of the technology and the utilization of the technology.

\section{General ICT availability and utilization}

\subsection{General trends in household use}

Reports of the Hungarian Central Statistical Office (KSH) in the field prove a clear improvement in computer usage among households [20]. $76 \%$ of the population were effective (active) computer users in 2015 , i.e. they used a computer at least once in a three-month period. While the indicator is lower than the EU average (83\%), a continuous increase can be observed in comparison with the previous years. $56.8 \%$ of the households had a desktop computer in 2009 and this ratio had barely changed to $2013(58.3 \%)$. Nevertheless, the share of portable computers has been growing steadily; the ratio has changed from $21 \%$ to $41.6 \%$ in the period.

Using ICT tools is usually associated with using the Internet. The growing number of households with Internet access is a positive tendency $(2009: 55 \% ; 2012: 69 \% ; 2015: 76 \%)$. 
The KSH report on telecommunications, Internet and TV services [1] pointed out that there were 9.1 million Internet subscriptions in Hungary in the 2nd quarter of 2017. It is to note, that is a five times increase over 10 years. Wired internet bandwidth has begun to grow dynamically; $75 \%$ were over $2 \mathrm{Mbit} / \mathrm{s}, 49 \%$ over $10 \mathrm{Mbit} / \mathrm{s}$ and $14 \%$ over $100 \mathrm{Mbit} / \mathrm{s}$ in 2016. The ratio of the latter category exactly doubled from the same period of the previous year. Development of data traffic on the wired Internet is remarkable. The traffic was about 383 thousand Terabytes, which means a 34\% increase over one year. Expansion has accelerated, which is proved by the fact that the value of the indicator was 39 thousand Terabytes in 2014 fourth quarter and 14.4 thousand Terabytes in 2010 fourth quarter based on data from KSH [19].

Furthermore, Internet subscriptions included 6.3 million Mobile Internet subscriptions. The most popular activities on the Internet are summarized in Table 1.

\begin{tabular}{|l|c|c|c|}
\hline & $\mathbf{2 0 1 4}$ & $\mathbf{2 0 1 5}$ & $\mathbf{2 0 1 6}$ \\
\hline Sending and receiving emails & 93.4 & 93.0 & 91.7 \\
\hline Internet telephony & 52.7 & 54.7 & 53.6 \\
\hline Visiting social sites & 79.3 & 83.4 & 82.8 \\
\hline Reading news & 85.6 & 85.7 & 88.1 \\
\hline $\begin{array}{l}\text { Information search for goods and } \\
\text { services }\end{array}$ & 13.6 & 83.3 & 88.0 \\
\hline Sharing own content & 14.4 & 58.1 & 45.6 \\
\hline Internet banking & 40.3 & 46.4 & 44.5 \\
\hline
\end{tabular}

Table 1: Internet utilization among active computer users (\%) [1]

\subsection{General trends in corporate use}

Sasvári [17] analyses the use of ICT tools on the corporate level. According to his results based on an international survey, the level of utilization is diverse, especially with regard to company size. Small- and medium-sized companies were lagging in using information systems [18]. Of course, this does not entail the total neglect of IT services and ICT tools, but the depth and scope of utilization are fairly questionable.

More than four-fifths of the corporations in the sample have a web page in 2010 and they used the Internet for advertising products and services. $60 \%$ of micro- and small companies have had a product or service advertised on the Internet. Moreover, internet banking was taken advantage of by $80 \%$ of micro and $85 \%$ of small companies.

Official statistics confirm Sasvári's findings. 91\% of the companies used the Internet in 2013, and $27 \%$ of them had broadband Mobile Internet access. However, there are areas for improvement, including:

- $\quad$ low utilization of cloud computing: only $26.2 \%$ of large companies (over 250 employees) took advantage of any cloud-based services (the national average ratio is $11.6 \%$ ),

- corporate web pages focused on product and service information; online ordering was available at $80 \%$ of them, however, every third company managed its purchasing also this way, 
- $\quad$ an enterprise resource planning system was installed by $70.5 \%$ of large companies but by only $37 \%$ of medium-sized (50-249 employees) and $12.1 \%$ of small firms (less than 50 employees) (KSH 2016).

In my opinion, the reason for this is not mainly the availability of the tools or even the financial possibilities. A large company can define a number of repeatable processes, which are manageable by IT systems, while a smaller company more rarely encounters with equally repetitive challenges. In these cases, individual treatment of the problem with marginal support of ICT can be more appropriate in several ways, including the costs. However, this means that personal IT competencies have fundamental importance in solving the problems.

\section{Survey Results}

\subsection{Time spent with ICT tools}

Smartphones and portable computers are the most popular ICT tools what the respondents have (Figure 2). The average time spent with them is about 4.5 hours a day for each. $62.2 \%$ of them has a television but only 2.5 hours are spent on it. Desktop computers are held by $42.2 \%$ of the respondents, however, daily use is 4.4 hours. The attractiveness of tablets is quite low, but it must be considered that the size of present smartphones is close to tablet-size [2].

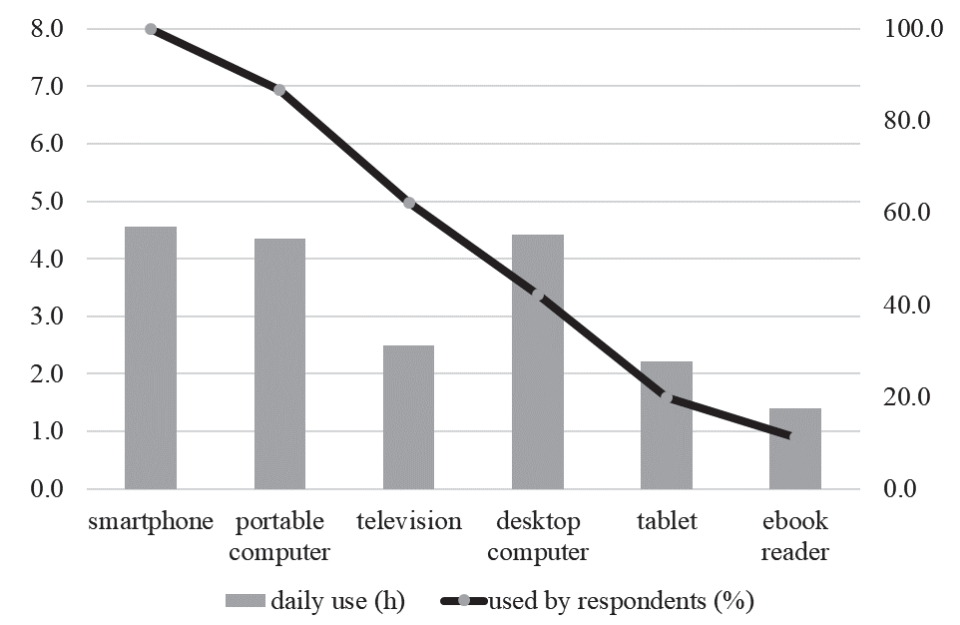

Figure 2: Utilization of some ICT tools in the sample 


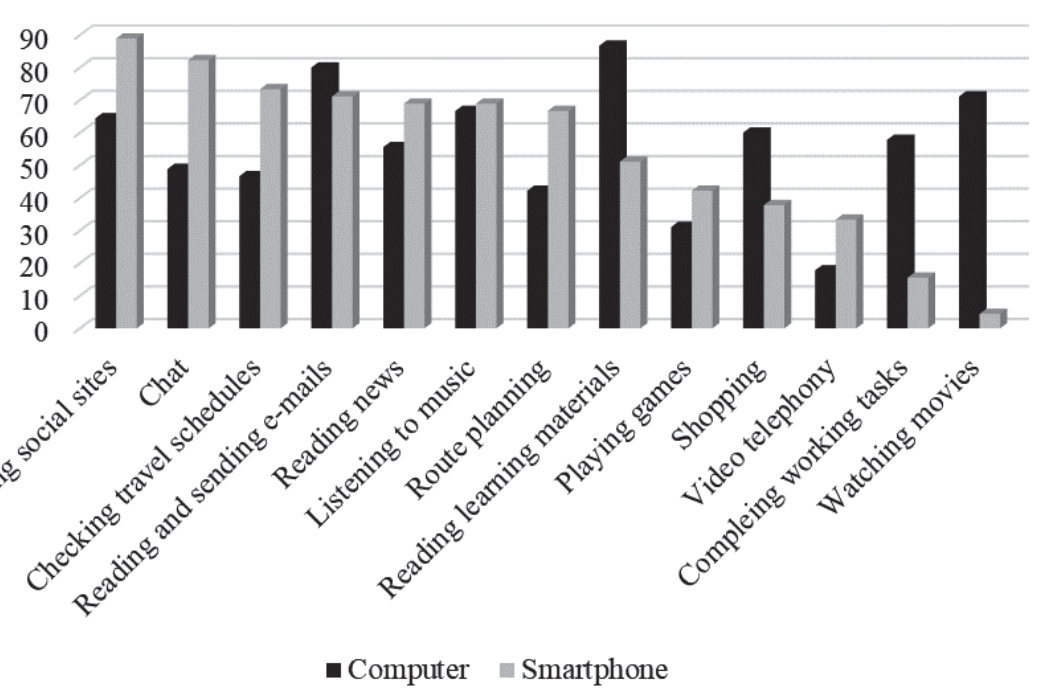

Figure 3: Activities realized with computers and smartphones in the sample (\%)

Beyond social presence or e-mails, it is forward-looking that $73.3 \%$ uses internet banking, 46,7\% uses the client portal of 'Ügyfélkapu'. $91.2 \%$ of them buy things on the internet, of which $35.6 \%$ oftentimes. The hypothesis of the research says that mobile devices take over the leading role. The survey asked some activities whether it is realized with desktop/portable computers or smartphones. Figure 3 shows that smartphones have a leading role e.g. in case of visiting social sites, chat, reading news and traveling issues. Computers are more popular in case of learning-support, work, shopping or watching movies.

\subsection{Competencies and satisfaction}

The survey asked the knowledge level about some basic software that may be necessary for the education and working. Based on the respondents' own declaration a very favorable emerges, however it must be added that former experiences [3] show that these answers are biased upward.

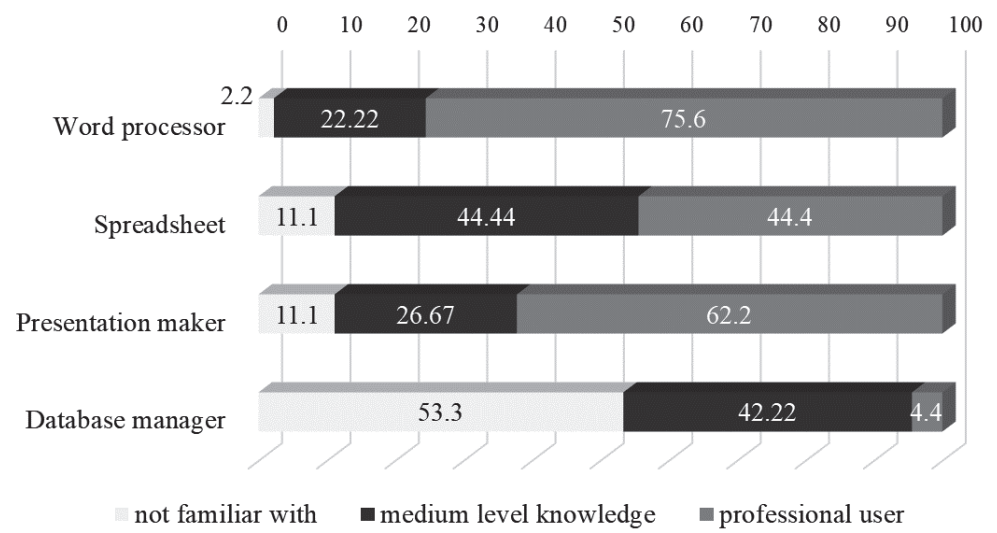

Figure 4: Competencies about office software in the sample(\%) 
$65.9 \%$ of the respondents are greatly satisfied with the performance of their desktop/portable computer, and $61.4 \%$ with the internet speed. The ratios of dissatisfied ones are $6.8 \%$ and $2.3 \%$. A special indicator of the satisfaction is whether people feel computer work exhausting (Figure 5). An additional information is that only $15.6 \%$ marked that he or she has a health problem (mainly vision problems) in context with computer work.

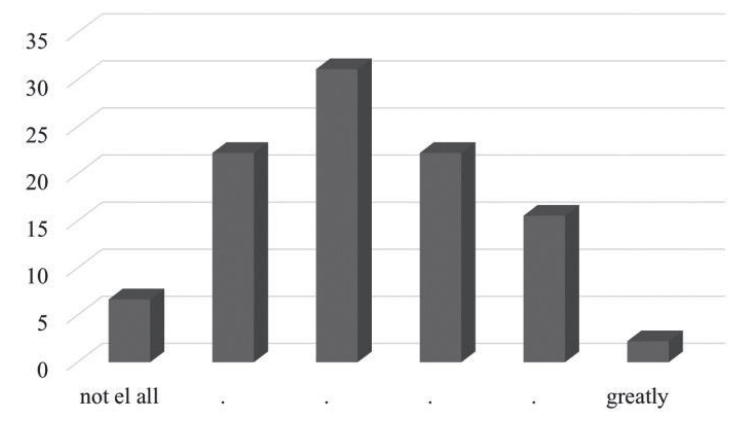

Figure 5: Distribution of the answers about feeling the computer work exhausting in the sample (\%)

IT education is inevitable in order to achieve a higher level of digital literacy. The survey asked the respondents to mark their satisfaction with the IT education of various study levels. Results in Figure 6 suggest the need for developing basic education; on the other hand, the performance higher education in this field is encouraging.

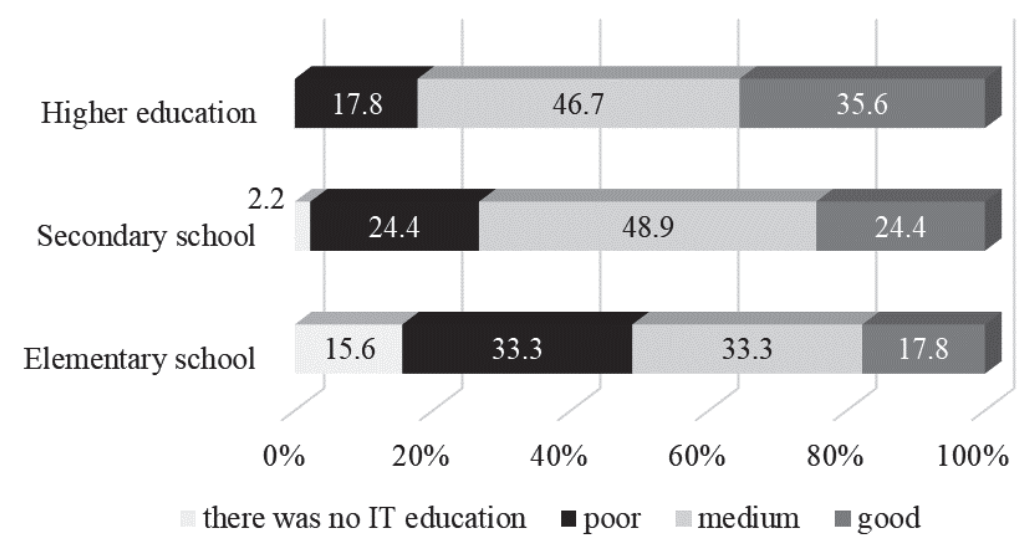

Figure 6: Satisfaction with IT education in the sample (\%)

\section{Conclusions}

\subsection{Experiences of the survey}

Both national level statistics and the survey results confirm that virtualization and mobilization determine our present. The pilot survey of public administration students show that IT-culture is not alienated from them, their activities are supported by ICT tools on a high level. Present students collect information and keep contact with others primarily through their smartphones. 
Considering that governmental development strategy force IT-based solutions (see [14], [15]), it is a progressive building stone that students' knowledge and approach are appropriate. However, the own competencies may be overestimated, and students feel lack of education, their commitment to ICT tools is encouraging. We believe that higher education has the responsibility to integrate workrelated skills and competencies with general knowledge.

\subsection{Further challenges of modeling}

Results show that the availability of ICT tools and IT infrastructure cannot be considered as the bottleneck of e-government services, i.e. the implemented strategic efforts were successful. The future challenge is to designate the effective ways of the utilization.

A practical limitation of the task-technology fit models is that technical elements cannot be evaluated without the accurate definition of the task to fit. Another condition of a comprehensive measurement model is a unified scale-system that was not feasible since that would have been with relevant information loss about the details of opinions.

The research presented in this paper allows defining general performance and utilization factors, moreover the considerable technological background. The survey allows comparing whether computers or smartphones are utilized more often to perform various tasks (Figure 3). Most of the tasks are entertainment-oriented utilization possibilities, work-related ones need further investigation. A separated approach is also suggested by an experience of the survey that is not partially presented in the paper: $81.8 \%$ of the respondents are very satisfied with the computer working environment at home, but only $50 \%$ of them at the work (18 respondents work full-time, part-time or an internship).

There are two main directions of future modeling:

- However, it would be looking forward to focusing on public administration tasks, this goes beyond the scope of the target group. Task-technology fit model in this scope will require the involvement of IT experts and clients; evaluation of technology, utilization and performance need their opinions.

- Furthermore, tasks that can be investigated directly in the target group are quite common, the work-related tasks are grouped around learning. Using this, we plan to develop a survey for higher education students and to compare the level if digital literacy among different levels and faculties.

\subsection{Acknowledgement}

This paper has been written with the support of the National University of Public Service in the framework of the priority project KÖFOP-2.1.2-VEKOP-15-2016-00001 titled "Public Service Development for Establishing Good Governance" - Ludovika Digital Governance Research Group. 


\section{References}

[1] Az infokommunikációs technológiák és szolgáltatások helyzete Magyarországon, 2016, Központi Statisztikai Hivatal, Budapest 2017.

[2] BERÉNYI, L., IKT-eszközök használata a jövő munkavállalóinál a Miskolci Egyetem gazdálkodási szakos hallgatóinak példáján keresztül, Közgazdász Fórum, 19, 126 (2016), 326.

[3] BERÉNYI, L., Számítógép-használat otthon és munkahelyen - digitális kompetencia és a számítógépes munkakörnyezet ergonómiájának empirikus vizsgálata. Vezetéstudomány. 44, 4 (2013), 51-62.

[4] D'AMBRA, J., WILSON, C. AND AKTER, S., Application of the task-technology fit model to structure and evaluate the adoption of Ebooks by academics. Journal of the American Society for Information Science and Technology, 64, 1 (2013), 48-64.

[5] DISHAW, M. T., AND STRONG, D. M., Extending the technology acceptance model with task-technology fit constructs, Information \& Management, 36 (1999), 9-21.

[6] ESHET-ALKALAI, Y., Digital literacy: a conceptual framework for survival skills in the digital era, Journal of Educational Multimedia and Hypermedia. 139, 1 (2004), 93-106.

[7] GARVIN, D. A., Managing Quality: The Strategic and Competitive Edge, The Free Press, New York 1988.

[8] GEBAUER, J., SHAW, M. J., AND GRIBBINS, M. L., Task-Technology Fit for Mobile Information Systems. Journal of Information Technology. 25, 2 (2010), 259-272.

[10] GOODHUE, D. L., AND THOMPSON, R. L., Task-Technology Fit and Individual Performance, MIS Quarterly, 19, 2 (1995), 213-236.

[11] ISAIAS, P., AND ISSA, T., High Level Models and Methodologies for Information Systems, New York, Springer 2015.

[12] LANKSHEAR, C., AND KNOBEL, M., Digital Literacies - Concepts, Policies and Practices, Peter Lang, New York 2008.

[13] LÜKÖ I., Az információs és a tanuló társadalom, Iskolakultúra, 13, 3 (2003), 102-110.

[14] NEMESLAKI, A., The Theory of "IT-Government" Alignment: Assessement of Strategic Fit in Hungary's Case. Proceedings of the Central and Eastern Europen eDem and eGov Days 2016, May 12-13, 2016, Budapest, 85-92.

[15] ORBÁN, A., A közigazgatási informatika alapjai, Nemzeti Közszolgálati Egyetem, Budapest 2013.

[16] PATAKI, B., Technomenenedzsment, L’Hartmann, Budapest 2014. 
[17] SASVÁRI, P. L. Az információs rendszerek kisvállalati alkalmazásának vizsgálata, magyarés horvátországi összehasonlító elemzés. Vezetéstudomány, 43, S.I. (2012), 56-65.

[18] SASVÁRI, P. L., AND WOLF, R., Austria and Hungary: Different stages of readiness to create added value by using business information systems, Pro Publico Bono - Magyar közigazgatás, 2, 3 (2014) 169-178.

[19] Távközlés, internet, 2014. IV. negyedév, Budapest, Központi Statisztikai Hivatal 2015.

[20] Távközlés, internet, televíziószolgáltatás, 2016. III. negyedév, Központi Statisztikai Hivatal, Budapest 2016. 